\title{
Invasive Heart Rate Control as a Salvage Therapy in Amiodarone-induced Thyroid Storm
}

\section{Amiodaron Kaynaklı Tiroid Fırtınasında Kurtarma Tedavisi Olarak invaziv Kalp Hızı Kontrolü}

\author{
(1) Emin Evren OZCAN1, (1) Mustafa DOCDUS2, (1) Resit Yigit YILANCIOGLU3, (1) Suleyman Cem ADIYAMAN4, \\ (1) Oguzhan Ekrem TURANI
}

IDokuz Eylul University Faculty of Medicine, Department of Cardiology; Heart Rhythm Management Center, Izmir, Turkey

2Usak University Training and Research Hospital, Clinic of Cardiology, Usak, Turkey

${ }^{3}$ Bornova Turkan Ozilhan State Hospital, Clinic of Cardiology, Izmir, Turkey

${ }^{4}$ Dokuz Eylul University Faculty of Medicine, Department of Endocrinology, Izmir, Turkey

\begin{abstract}
Atrial fibrillation (AF) is the most common arrhythmia, and amiodarone is one of the most commonly used drugs for medical cardioversion of $A F$, which should be used carefully due to its toxic effects. Amiodaroneinduced thyrotoxicosis (AIT) may develop in amiodarone-treated patients. In contrast, the most common rhythm disturbance accompanying a thyroid storm is AF. This association may put both $\mathrm{AF}$ and thyrotoxicosis treatment into a vicious circle, leading to Al cardiomyopathy. Herein we aimed to present atrioventricular node ablation as a salvage therapy in a patient with AIT who had AF-causing hemodynamic impairment, resistance to medical therapy, and cardioversion.

Keywords: Atrial fibrillation, thyrotoxicosis, AV node ablation
\end{abstract}

\section{öz}

Atriyal fibrilasyon (AF) en sık görülen aritmidir ve amiodaron, $A F^{\prime}$ nin medikal kardiyoversiyonunda en sık kullanılan ve toksik etkileri nedeniyle dikkatli kullanılması gereken ilaçlardan biridir. Amiodaron ile tedavi edilen hastalarda amiodaron ile indüklenen tirotoksikoz (AIT) gelişebilir. Buna karşılık, bir tiroid fırtınasına eşlik eden en yaygın ritim bozukluğu AF'dir. Bu ilişki hem AF hem de tirotoksikoz tedavisini kısır bir döngüye sokabilir ve aritmi kaynaklı kardiyomiyopatiye yol açabilir. Burada hemodinamik bozukluğa neden olan, medikal tedaviye ve kardiyoversiyona dirençli AF'si olan bir AiT hastasında kurtarma tedavisi olarak atriyoventriküler düğüm ablasyonunu sunmayı amaçladık.

Anahtar kelimeler: Atriyal fibrilasyon, tirotoksikoz, AV dügüm ablasyonu

\section{INTRODUCTION}

Atrial fibrillation (AF) is the most common sustained arrhythmia and is associated with increased mortality and stroke incidences'. Comorbidities such as thyrotoxicosis, valve disorders, and atherosclerosis may cause AF and make it difficult to control. Amiodarone is an iodinecontaining medical agent used in many different types of arrhythmias. It may cause toxicity in the eyes, lungs, thyroid, and liver ${ }^{2}$. Amiodarone-induced thyrotoxicosis (AIT) develops in 3-10\% of amiodarone-treated patients ${ }^{3,4}$. In contrast, the most common rhythm disturbance accompanying a thyroid storm is $\mathrm{AF}^{5}$. This association may put both AF and thyrotoxicosis treatment into a vicious circle, leading to Al cardiomyopathy. We aimed to present atrioventricular (AV) node ablation as a salvage therapy in a patient with AIT who had AF-causing hemodynamic impairment, resistance to medical therapy, and cardioversion.

\section{CASE REPORT}

Written informed consent was obtained from the patient for the publication of this case report and accompanying images.

Address for Correspondence:I. M. Dogdus, Usak University Training and Research Hospital, Clinic of Cardiology, Usak, Turkey

E-mail: mdogdus@hotmail.com ORCID ID: orcid.org/0000-0002-3895-1923

Received: 05 January 2022

Accepted: 28 January 2022

Online First: 18 February 2022 
A 45-year-old male patient with a history of mitral valve replacement surgery, AF, and heart failure with mildly reduced ejection fraction was admitted to an external center with complaints of breathlessness and palpitations. Electrocardiogram (ECG) revealed AF with a high ventricular response. First, the rhythm control strategy was used with an amiodarone infusion, followed by external electrical cardioversion. High-dose betablocker and digoxin were given with amiodarone for rate control when rhythm control could not be achieved. Due to failure of a ventricular response rate control, additional amiodarone infusion (approximately $4 \mathrm{~g}$ ) was administered to the patient in the external center. The patient was followed-up in the external center for 7 days. A daily intravenous infusion of about 1-g amiodarone was given for 4 days. Peroral maintenance amiodarone was not given. The heart rate still could not be controlled. Along with the worsening of the patient's initial complaints, a progressive decrease in the left ventricular ejection fraction (LVEF) was detected (from $45 \%$ to $20 \%$ ). Therefore, the patient was implanted with an implantable cardioverter defibrillator (ICD) for primary prevention at the external center.

The patient was referred to our center due to frequent ICD shocks in an electrical storm and decompensated heart failure. He had low flow symptoms and frequent ICD shocks. In his physical examination, cachexia, arrhythmic heart sounds, tachycardia, and bilateral crepitant rales were detected. Initial ECG revealed a rapid ventricular response AF (Figure 1). Echocardiography showed LVEF of $20 \%$ and global hypokinesia. ICD recordings showed inappropriate ICD shocks due to $A F$, and sinus rhythm could not be achieved despite these shocks. We did not give additional IV or peroral amiodarone after transferring the patient.

Laboratory tests showed free $\mathrm{T}_{4}$ value of $26 \mathrm{ng} /$ $\mathrm{dL}$ (normal range: 0.7-1.9 $\mathrm{ng} / \mathrm{dL}$ ); thyroid stimulating hormone was $<0.01 \mu \mathrm{lU} / \mathrm{mL}$ (normal range: $0.38-3.80 \mu \mathrm{lU}$ / $\mathrm{mL}$ ); and free $\mathrm{T}_{3}$ was $9.5 \mathrm{pg} / \mathrm{mL}$ (normal range: $1.4-3.8 \mathrm{pg} /$ $\mathrm{mL}$ ). No other remarkable abnormalities were observed. Chest $X$-ray revealed the bilateral pleural effusion and cardiomegaly. Thyroid auto-antibody results were negative. AIT was considered the underlying etiology of tachycardia. Immediately, antithyroid treatment of methimazole $2 \times 30 \mathrm{mg}$ and prednisolone $2 \times 40 \mathrm{mg}$ was started. Repeated electrical cardioversion was performed after no thrombus was observed by the transesophageal echocardiography. General condition of the patient deteriorated gradually. Because the general condition and hemodynamic status of the patient were unstable, total thyroidectomy and/or radioactive iodine (RAI) treatment was not considered appropriate according to a multidisciplinary decision.

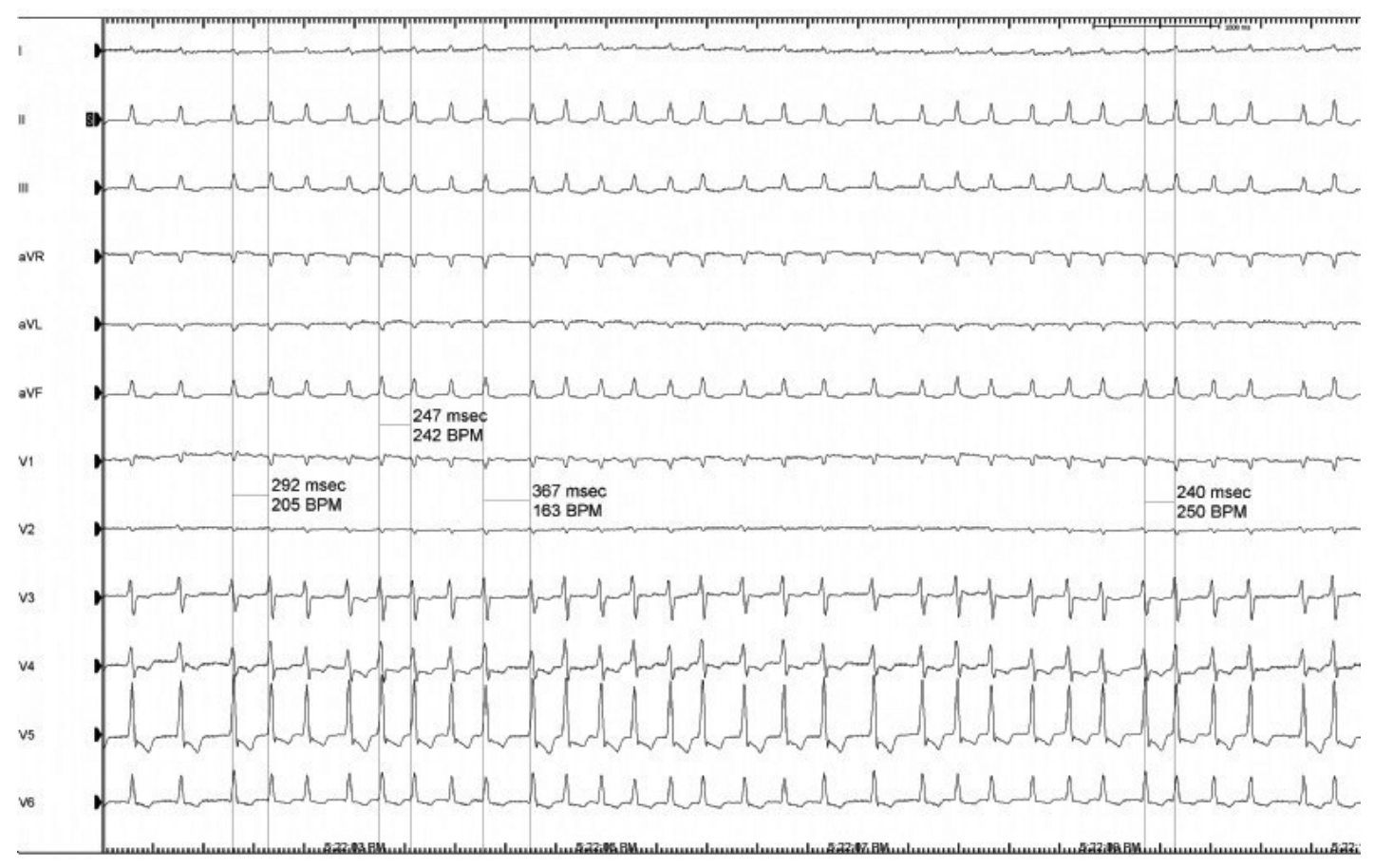

Figure 1. Baseline electrocardiogram showed atrial fibrillation with rapid ventricular response. 
AV node ablation was planned to arrange the ventricular response for a uncontrolled AF. AV node ablation procedure was applied to the area where the proximal $\mathrm{AV}$ node and supraventricular signals of the patient were recorded with the radiofrequency ablation catheter for 120 seconds, with an average power of 50 watts and $52^{\circ}$. After the procedure, permanent complete $\mathrm{AV}$ block was achieved (Figure 2), and the heart rate was $100 \mathrm{bpm}$. Significant reduction in the symptoms was observed immediately after the successful procedure, followed by uneventful patient recovery. In the echocardiographic examination performed 3 days later, a significant improvement was found with a LVEF of $40 \%$. On discharge, the basal heart rate was $80 \mathrm{bpm}$. Methimazole $(2 \times 15 \mathrm{mg})$ and prednisolone $(2 \times 16 \mathrm{mg})$ were given.

During his follow-up, it was observed that the AV conduction improved the functional capacity of the patient, and thyroid hormone values reached normal limits. At the third month after discharge, methimazole and prednisolone treatments were completely stopped. The patient has been followed-up for 3 years with AF with a normal ventricular response without any symptoms.

\section{DISCUSSION}

Patients with AIT may present with clinical scenarios ranging from palpitation to a progressive hemodynamic impairment. The effects of amiodarone on the thyroid gland could be seen within days after starting treatment and/or up to several months after its discontinuation ${ }^{6}$. Because of the differences in the pathophysiology and treatment modality, AIT cases are divided into two subtypes. Type-1 AIT (AIT) is mentioned when there is an increase in thyroid hormones due to excess iodine in the patients with a concomitant thyroid disease, such as nodular goiter or Graves' disease. Type-2 AIT (AIT $)$ is a condition in which thyroid hormones are released due to cell damage caused by the direct cytotoxic effect of amiodarone on thyroid follicular cells in patients with a healthy thyroid gland ${ }^{7}$. The thyrotoxicosis results in an excess release of the preformed $T_{3}$ and $T_{4}$ into the circulation ${ }^{8}$. The iodine-131 uptake test could help to differentiate $\mathrm{AIT}_{1}$ from $\mathrm{AIT}_{2}$. AIT 1 is treated with a thionamide (methimazole 30-40 mg daily), and $\mathrm{AIT}_{2}$ is treated with the glucocorticoids. The European Thyroid Association recommends total thyroidectomy and/ or RAl treatment in case of a deteriorating cardiac function in the AIT 9 . Because the general condition and

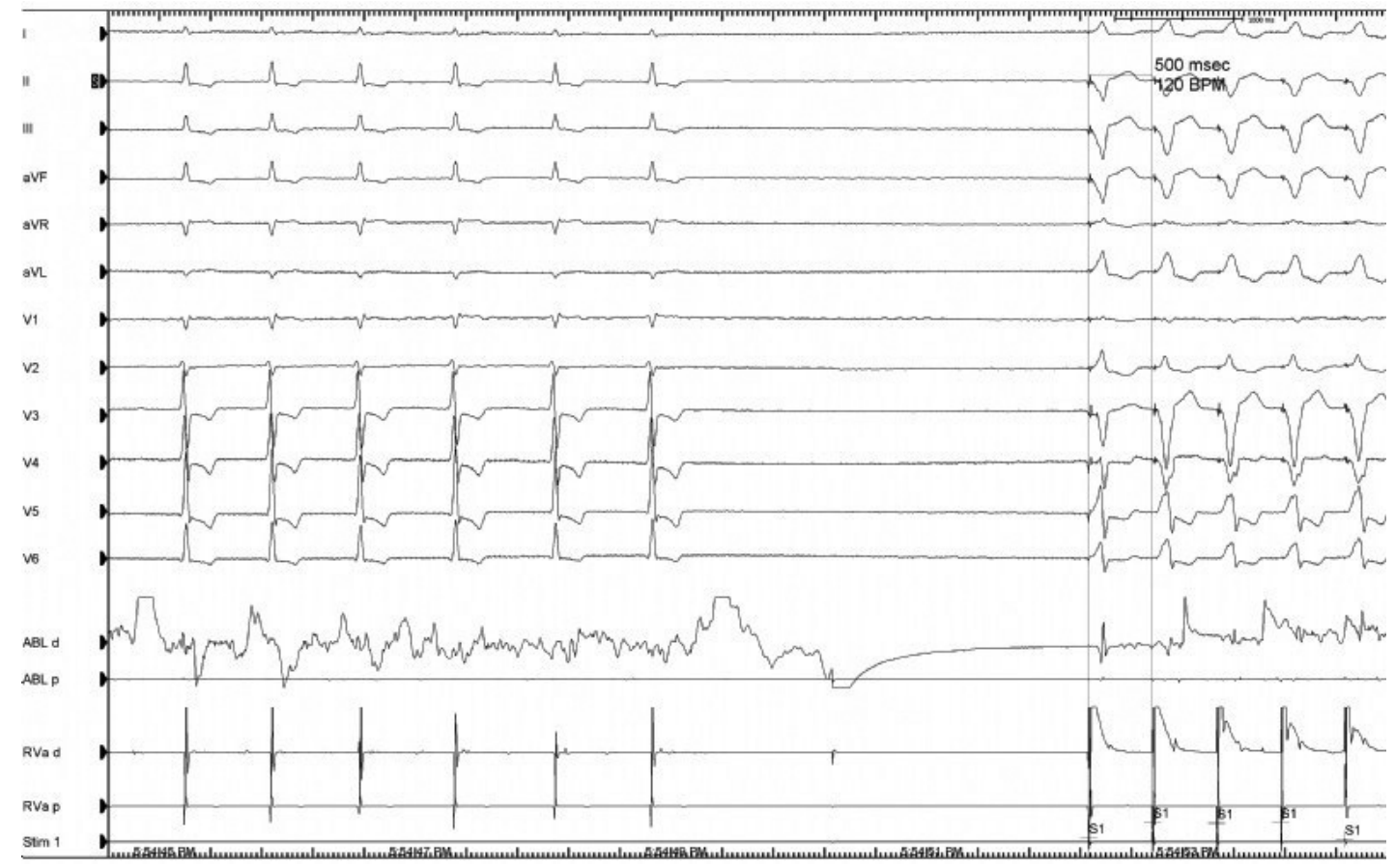

Figure 2. On the left side of the electrocardiogram, it is seen that the ventricular response slows down and ends with RF ablation, and on the right side of the electrocardiogram, heartbeats start a few seconds later.

RF: Radio-frequency 
hemodynamic status of our patient were unstable, total thyroidectomy and/or RAI treatment was not considered appropriate according to a multidisciplinary decision.

AF may have an impact on hemodynamics and symptoms. One of the main AF management strategies is the control of heart rate. Amiodarone may be a good option for the acute treatment of patients with heart failure. Electrical cardioversion should be considered when medical therapy fails to control the heart rate. If all noninvasive methods fail, invasive therapies, such as AV node ablation and permanent pacing, are considered. Ablation of the AV node is an effective therapy and with almost $100 \%$ success rates ${ }^{10,11}$. Our patient had AIT aggravated AF with failed medical and electrical cardioversion. Radiofrequency catheter ablation of $\mathrm{AV}$ node relieved symptoms and improved the patient's functional status.

AV node ablation improves symptoms and cardiac function in patients with AF by controlling the heart rate. Moreover, ventricular desynchrony develops due to a permanent right ventricular pacing, and worsening of LVF may be observed. The recent Ablate and Pace for Atrial Fibrillation-cardiac resynchronization therapy (APAF-CRT) trial showed that AV node ablation + CRT was superior to pharmacotherapy in reducing mortality in patients with permanent AF and narrow QRS'2. Our patient previously had an ICD implanted as a primary prevention. The functional status of our patient was New York Heart Association class 1, LVEF was improved, and the patient's AV conduction recovered in the follow-up. Therefore, CRT-D upgrade was not planned.

In conclusion, thyroid storm could be triggered by amiodarone toxicity. AV node ablation should be considered a salvage therapy in patients who have a hemodynamic vicious circle during thyroid storm and have pacemaker/ICD implanted due to the other indications. In addition, ICD implantation may have catastrophic consequences in patients without appropriate heart rate control.

\section{Ethics}

Informed Consent: Written informed consent was obtained from the patient for the publication of this case report and accompanying images.

Peer-review: Externally peer-reviewed.

\section{Author Contributions}

Surgical and Medical Practices: E.E.O., O.E.T., Concept: E.E.O., M.D., O.E.T., Design: E.E.O., M.D., R.Y.Y., Data Collection and/or Processing: E.E.O., O.E.T., S.C.A.,
M.D., Analysis and/or Interpretation: M.D., O.E.T., S.C.A., Literature Search: E.E.O., M.D., O.E.T., R.Y.Y., Writing: M.D., O.E.T., R.Y.Y.

Conflict of Interest: The authors declare that they have no conflict of interest.

Financial Disclosure: The authors declared that this study has received no financial support.

\section{REFERENCES}

1. Kirchhof P, Benussi S, Kotecha D, et al. 2016 ESC Guidelines for the management of atrial fibrillation developed in collaboration with EACTS. Eur Heart J. 2016;37:2893-962.

2. Goldschlager N, Epstein AE, Naccarelli G, Olshansky B, Singh B. Practical guidelines for clinicians who treat patients with amiodarone. Practice Guidelines Subcommittee, North American Society of Pacing and Electrophysiology. Arch Intern Med. 2000;160:1741-8.

3. Martino E, Safran M, Aghini-Lombardi F, et al. Environmental iodine intake and thyroid dysfunction during chronic amiodarone therapy. Ann Intern Med. 1984;101:28-34.

4. Bouvy ML, Heerdink ER, Hoes AW, Leufkens HG. Amiodaroneinduced thyroid dysfunction associated with cumulative dose. Pharmacoepidemiol Drug Saf. 2002;11:601-6.

5. Marrakchi S, Kanoun F, Idriss S, Kammoun I, Kachboura S. Arrhythmia and thyroid dysfunction. Herz. 2015;40(Suppl 2):1019.

6. Cardenas GA, Cabral JM, Leslie CA. Amiodarone-induced thyrotoxicosis: Diagnostic and therapeutic strategies. Cleve Clin J Med. 2003;70:628-31.

7. Souza LVF, Campagnolo MT, Martins LCB, Scanavacca MI. Amiodarone-Induced Thyrotoxicosis - Literature Review \& Clinical Update. Arq Bras Cardiol. 2021;117:1038-44.

8. Newman CM, Price A, Davies DW, Gray TA, Weetman AP. Amiodarone and the thyroid: A practical guide to the management of thyroid dysfunction induced by amiodarone therapy. Heart. 1998;79:121-7.

9. Bartalena L, Bogazzi F, Chiovato L, Hubalewska-Dydejczyk A, Links TP, Vanderpump M. 2018 European Thyroid Association (ETA) guidelines for the management of amiodarone - associated thyroid dysfunction. Eur Thyroid J. 2018;7:55-66.

10. García Gil D, Escobar Jiménez L, Piñero Gálvez C, Girón González JA. Ablation of the hyperconducting atrioventricular node in a patient with thyrotoxicosis induced by amiodarone. Med Clin (Barc). 1995;105:238.

11. Marshall HJ, Griffith MJ. Ablation of the atrioventricular junction: technique, acute and long-term results in 115 consecutive patients. Europace. 1999;1:26-9.

12. Brignole $M$, Pentimalli $F$, Palmisano $P$, et al. AV junction ablation and cardiac resynchronization for patients with permanent atrial fibrillation and narrow QRS: the APAF-CRT mortality trial. Eur Heart J. 2021;42:4731-9. 